\title{
CLOSING CANADA'S DIGITAL DIVIDE: \\ A REVIEW OF POLICIES IN CANADA AND ABROAD
}

by

Charlie Crabb

A Major Research Paper
presented to Ryerson University
in partial fulfillment of the requirements for the degree of Master of Digital Media

In the Yeates School of Graduate Studies Ryerson University

Toronto, Ontario, Canada

(c) Charlie Crabb, 2017 


\section{Author's Declaration}

I hereby declare that I am the sole author of this MRP. This is a true copy of the MRP, including any required final revisions. I authorize Ryerson University to lend this MRP to other institutions or individuals for the purpose of scholarly research. I further authorize Ryerson University to reproduce this MRP by photocopying or by other means, in total or in part, at the request of other institutions or individuals for the purpose of scholarly research. I understand that my MRP may be made electronically available to the public. 


\section{Abstract}

This paper explores Canada's telecommunications policy landscape, with an aim of evaluating its effect on Canada's digital divide. It looks into decisions made by the CRTC and ISED (and its predecessors), which have influenced the development of broadband infrastructure in Canada. This paper also evaluates the efficacy of digital literacy training programs, aimed at allowing Canadians to leverage connectivity. Finally, it concludes with a discussion about how the Innovation Agenda can be used as a mechanism to narrow Canada's digital divide 


\section{Acknowledgements}

Thank you to all the wonderful staff and faculty at Ryerson, who've made this year an incredible learning experience. I would like to especially thank Michael Carter, Sonya Taconne, Dr. Alex Ferworn, Ben Rich and Am Sagarwala for their guidance throughout the year. Dr. Catherine Middleton, for her patience and mentorship over the last six months. Finally, my parents, who without l'd would be so, so lost. Thank you! 


\section{Table of Contents}

$\begin{array}{ll}\text { Author's Declaration } & 1\end{array}$

$\begin{array}{ll}\text { Abstract } & 2\end{array}$

Acknowledgements $\quad 3$

$\begin{array}{ll}\text { Table of Contents } & 4\end{array}$

$\begin{array}{lr}\text { Introduction } & 5\end{array}$

$\begin{array}{ll}\text { Canada's Digital Divide and Why It Matters } & 7\end{array}$

Evolution of Broadband Policy and Forbearance in Canada 17

$\begin{array}{ll}\text { Mobile Wireless Services } & 19\end{array}$

Fixed Broadband Market Interventions $\quad 26$

$\begin{array}{ll}\text { The impact of the free market } & 32\end{array}$

Cracking The Digital Literacy Issue: Canada \& Abroad 34

Discussion: A Framework for Canada's Innovation Agenda for Social Good 39

1. A national broadband strategy, which details mechanisms for spurring investment in both mobile and fixed broadband projects.

2. A digital literacy strategy, which maps current initiatives throughout the country, with a gap analysis and solutions for closing those gaps.

3. A research strategy to unveil best practices for developing NGN in underserved areas, including $5 \mathrm{G}$ and fibre optic networks

References 46 


\section{Introduction}

This paper examines policies used to close Canada's digital divide. From how we are entertained to how we work, nearly every aspect of life is shifting to digital. This means we are becoming increasingly reliant on access to broadband and digital skills to participate in social and economic activities.

Canada's federal government often takes a passive approach to achieving policy objectives. Funds are routinely dispensed to NGOs, the private sector and other players to support initiatives or projects with the aim of maximising social and economic good. While this approach can lead to positive outcomes, it has led to mixed results in the provision of broadband services and digital skills training.

The public sector has a role to play in advancing Canada's digital economy. Policy makers are supporting initiatives and policies that encourage the deployment of mobile and fixed broadband infrastructure and digital literacy programs to ensure Canadians survive, let alone thrive, in the digital economy. It's a necessity. Around the globe, developed nations are heavily investing in both training initiatives and network infrastructure, which will be the bedrock of many business ecosystems, including e-commerce, waste management, agri-tech, the gig economy and more (World Bank 2017, iii - vi).

However, Canadians may be better served by a heavier hand, guiding the market that provides access to the digital economy. As it stands, Canada's regulatory 
environment may perpetuate, or do little to solve, a few persistent problems. While high-quality telecommunications services are accessible in highly populated pockets of the country, many regions and demographics remain underserved, including rural communities, indigenous reserves, and lower-class families. It resulted in one of the starkest 'digital divides' among OECD countries (Statistics Canada 2015). Pieces of legislation created before the advanced development of the global digital economy handcuff regulatory efforts aimed at resolving the issue. It has created an insular environment for Canada's incumbent telecommunication companies to thrive, by internally allowing the free market to reign supreme, while blocking foreign, market-disruptive players from entering in.

While strides have been made to protect consumers and narrow the divide, prices for telecommunications services remain high, and penetration rates remain low, relative to other developed nations (World Bank 2017). The Canadian Radio Telecommunications Commission (CRTC, the telecommunications regulator) and Innovation Science and Economic Development (ISED, the federal government department responsible for ensuring access to the digital economy) have operated on the periphery of the issue, by playing within the constraints of the 1993 Telecommunications Act and introducing piecemeal initiatives, which often fail to make meaningful change. Neither body has systematically addressed the core roots of the problem-a lack of availability and/or affordable access to telecommunications services and population-wide digital literacy skills training- indicating that an alternative 
approach is required. Stronger industry oversight by the CRTC might be needed, as J.P. Blais suggested after he departed as chairman of the commission (Financial Post 2017).

As suggested by Belloc, Nicita and Rossi (2012), public investment in broadband networks is worthwhile, as it provides a significant stimulus to broadband penetration. In choosing policy tools, decision makers should utilise both supply-side and demand-side strategies to stimulate growth. Governments should also devise coherent strategies and avoid adopting piecemeal interventions. While Canada has introduced interventions to help eradicate the digital divide, for the most part, they have been fragmented stopgaps (McNally et al., 2015, provide a detailed list of multiple, but incomplete provincial and federal initiatives supporting broadband rollout across the country). Other nations have formulated more robust, cohesive strategies, encapsulating not only filling network gaps-through funds and public/private initiatives-but also closing knowledge and digital literacy gaps.

Canada's digital divide is not unique. Most developed nations have a gap to some degree, (Statistics Canada, 2013). The purpose of this research project is to analyse Canada's current divide, what's currently being done to remedy it and then contrasting those efforts with other countries' solutions. It analyses plans to develop fixed broadband networks, mobile broadband networks and digital literacy strategies. The findings of this study will provide insights for developing a framework for closing Canada's divide. 


\section{Canada's Digital Divide and Why It Matters}

Social divides in Canada may always persist. Canada is vast and diverse, which often results in different interests and priorities from region to region. With that said, every Canadian should have access to the same opportunities and services regardless of their ideology, geography or economic standing. That includes access to health care, education and other essential services, which now includes access to broadband internet, as declared by the CRTC in December 2016 (CRTC 2016a). In emphasising the importance of access to broadband, the CRTC (2016a) stated:

\footnotetext{
“Telecommunications services to Canada's future economic prosperity, global competitiveness, social development and democratic discourse...in particular fixed and mobile wireless broadband Internet access services are catalysts for innovation and underpin a vibrant, creative, interactive world that connects Canadians across vast distances and with the rest of the world."
}

In addition to declaring access to broadband as a basic service, the CRTC (2016a) attached new service quality goals to its decisions:

1. "Canadian residential and business fixed broadband Internet access service subscribers should be able to access speeds of at least 50 megabits per second (Mbps) download and $10 \mathrm{Mbps}$ upload and to subscribe to a service offering with an unlimited data allowance." 
2. "the latest generally deployed mobile wireless technology should be available not only in Canadian homes and businesses but on as many major transportation roads as possible in Canada." (CRTC, 2016a)

While these goals are admirable, Canada has a long, arduous road before it can fully realise them. The relationship between Canadians and access to affordable broadband is complicated. To date, the country's regulatory environment, highly concentrated market and sheer physical size have left many Canadians underserviced and paying among the highest rates for broadband in the world (OECD 2015).

For instance, availability of quality broadband varies from province to province, as shown in Figure 1 below.

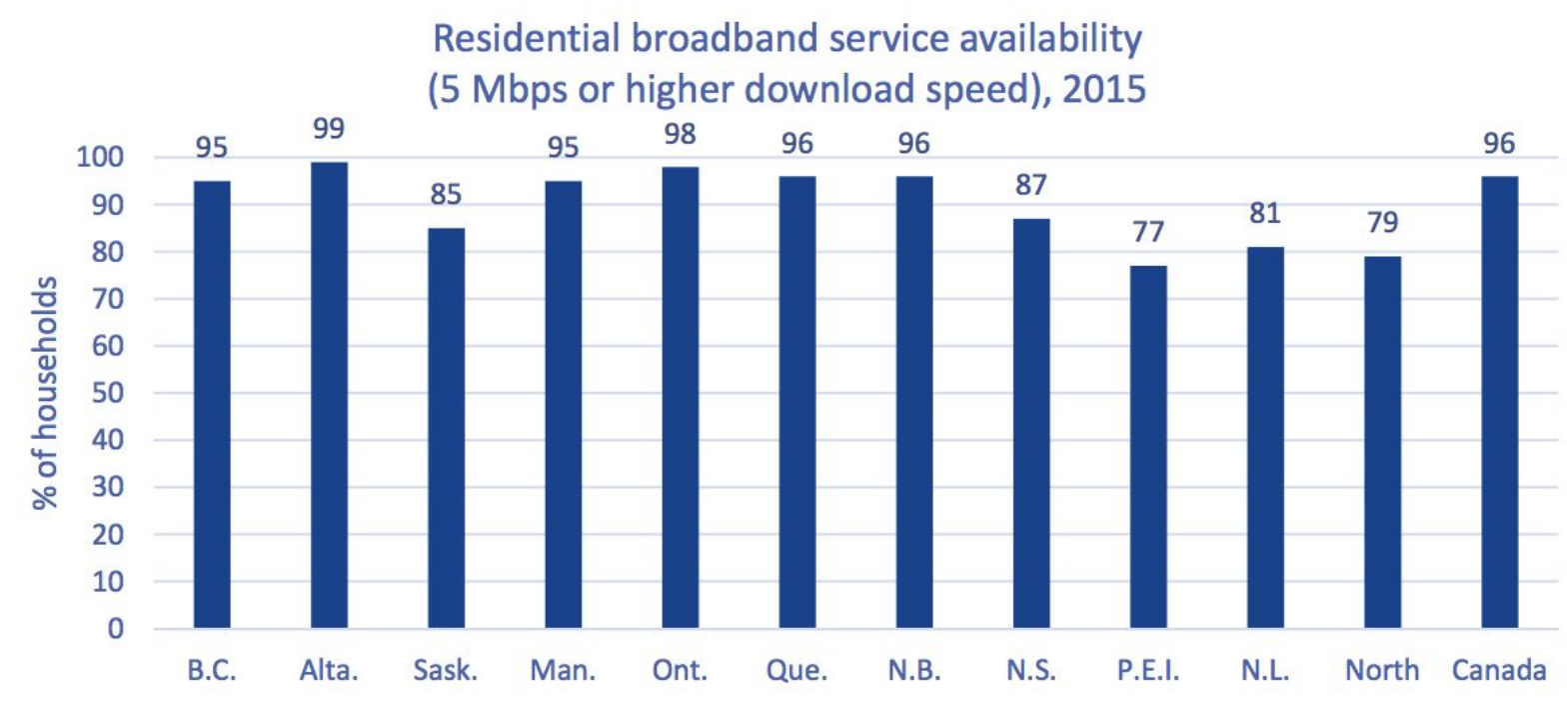

Figure 1, (2016 Communications Monitoring Report (CMR), CRTC 2016b) 
Figure 1 only illustrates the availability of broadband at speeds up to $5 \mathrm{Mbps}$ per second, well below the CRTC's current target of 50 Mbps down (CRTC, 2016a). Figure 2 shows the variation of broadband service availability between provinces/territories (CRTC 2016b).

Table 5.3.16 Broadband service availability, by speed and province/territory (\% of households), 2015

\begin{tabular}{cc|c|c|c|c|c|c}
\hline Province/territory & $\begin{array}{c}\mathbf{1 . 5}-\mathbf{4 . 9} \\
\text { Mbps }\end{array}$ & $\begin{array}{c}\mathbf{1 . 5 - 4} \\
\text { Mbps } \\
\text { with } \\
\text { HSPA+ }\end{array}$ & $\begin{array}{c}\mathbf{5 - 9 . 9} \\
\text { Mbps }\end{array}$ & $\begin{array}{c}\mathbf{5 - 9 . 9} \\
\text { Mbps } \\
\text { with LTE }\end{array}$ & $\begin{array}{c}\mathbf{1 0 - 1 5 . 9} \\
\text { Mbps }\end{array}$ & $\begin{array}{c}\mathbf{1 6 - 2 4 . 9} \\
\text { Mbps }\end{array}$ & $\begin{array}{c}\mathbf{2 5} \text { Mbps } \\
\text { or } \\
\text { higher }\end{array}$ \\
\hline British Columbia & 97 & 99 & 95 & 98 & 92 & 90 & 89 \\
\hline Alberta & 99 & 99.9 & 99 & 99.8 & 95 & 94 & 93 \\
\hline Saskatchewan & 91 & 99 & 85 & 91 & 76 & 61 & 59 \\
\hline Manitoba & 98 & 99.7 & 95 & 96 & 85 & 74 & 74 \\
\hline Ontario & 99 & 99.8 & 98 & 99.6 & 96 & 94 & 94 \\
\hline Quebec & 97 & 99 & 96 & 98 & 91 & 86 & 86 \\
\hline New Brunswick & 97 & 99.7 & 96 & 99 & 94 & 94 & 94 \\
\hline Nova Scotia & 99.8 & 99.9 & 87 & 99 & 84 & 83 & 81 \\
\hline Prince Edward Island & 93 & 99.9 & 77 & 99.9 & 61 & 61 & 55 \\
\hline Newfoundland and Labrador & 85 & 97 & 81 & 93 & 69 & 69 & 60 \\
\hline Yukon & 97 & 97 & 97 & 97 & 69 & 69 & 62 \\
\hline Northwest Territories & 97 & 97 & 92 & 92 & 72 & 72 & 48 \\
\hline Nunavut & 99.9 & 99.9 & 29 & 29 & 0 & 0 & 0 \\
\hline
\end{tabular}

Sources: Innovation, Science and Economic Development Canada (ISED) and CRTC data collection

Figure 2, (2016 Communications Monitoring Report (CMR), CRTC 2016b)

Simply put, the above charts reveal significant discrepancies in quality and availability of broadband service on a region to region basis. Gaps in availability are often in rural and remote areas of the country, which do not provide sufficient return on investment for telecommunication service providers. Also, where service is available, affordability of broadband service again varies from region to region, which may also affect Canadians' ability to access broadband. Figure 4 demonstrates price discrepancies between urban and rural areas for access to broadband services. While 
investing in network infrastructure is expensive, deploying it is substantially cheaper than building roads, gas lines and other traditional forms of infrastructure, as shown in Figure 3 below (BDO Canada 2017).

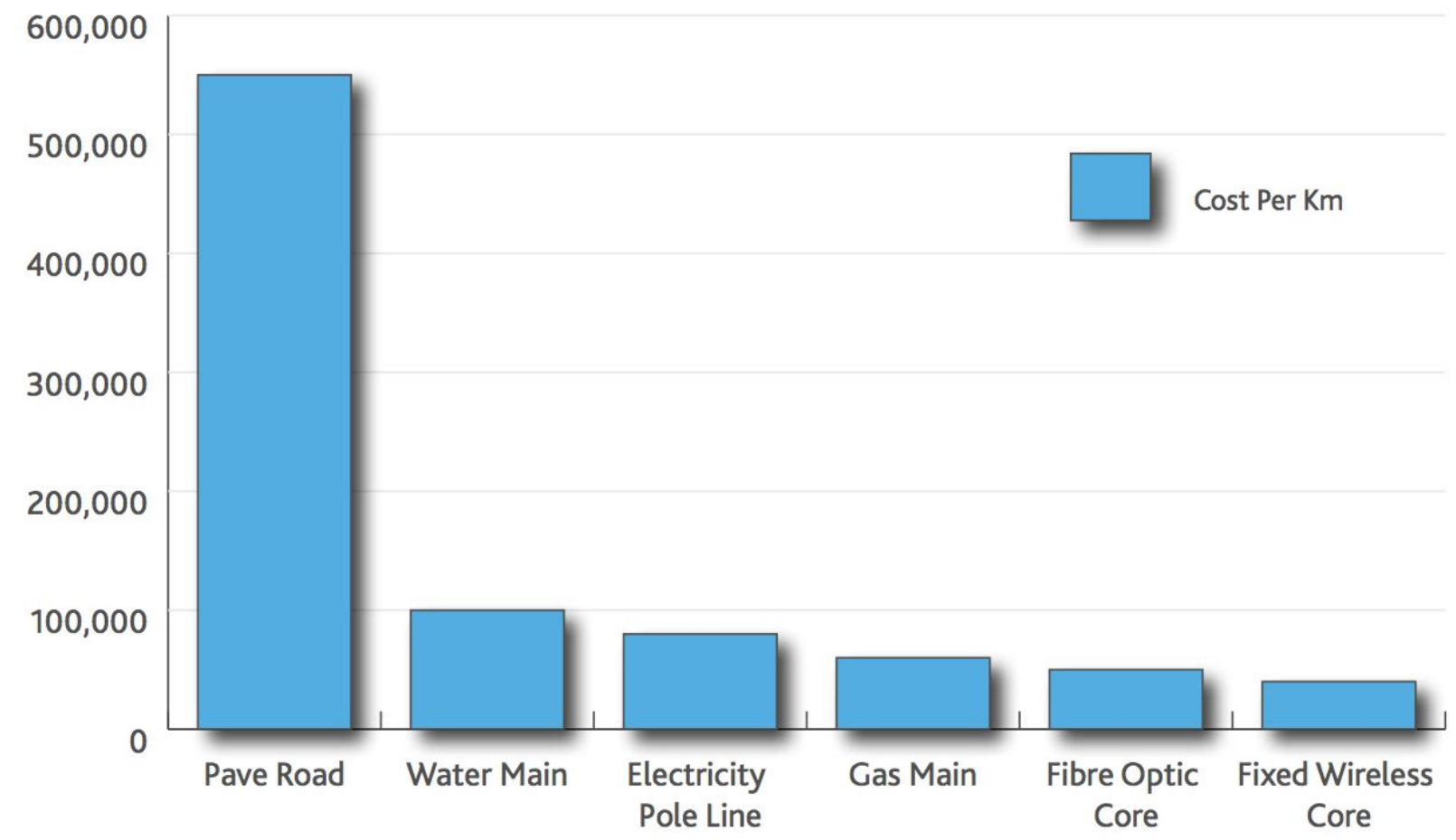

Figure 3 (BDO Canada 2017). 
Figure 5.3.4 Price comparison of residential broadband (5 Mbps) Internet access service and number of companies providing this service in urban and rural communities, 2015

Price comparison of residential broadband ( $5 \mathrm{Mbps}$ ) Internet access service in urban and rural communities, 2015

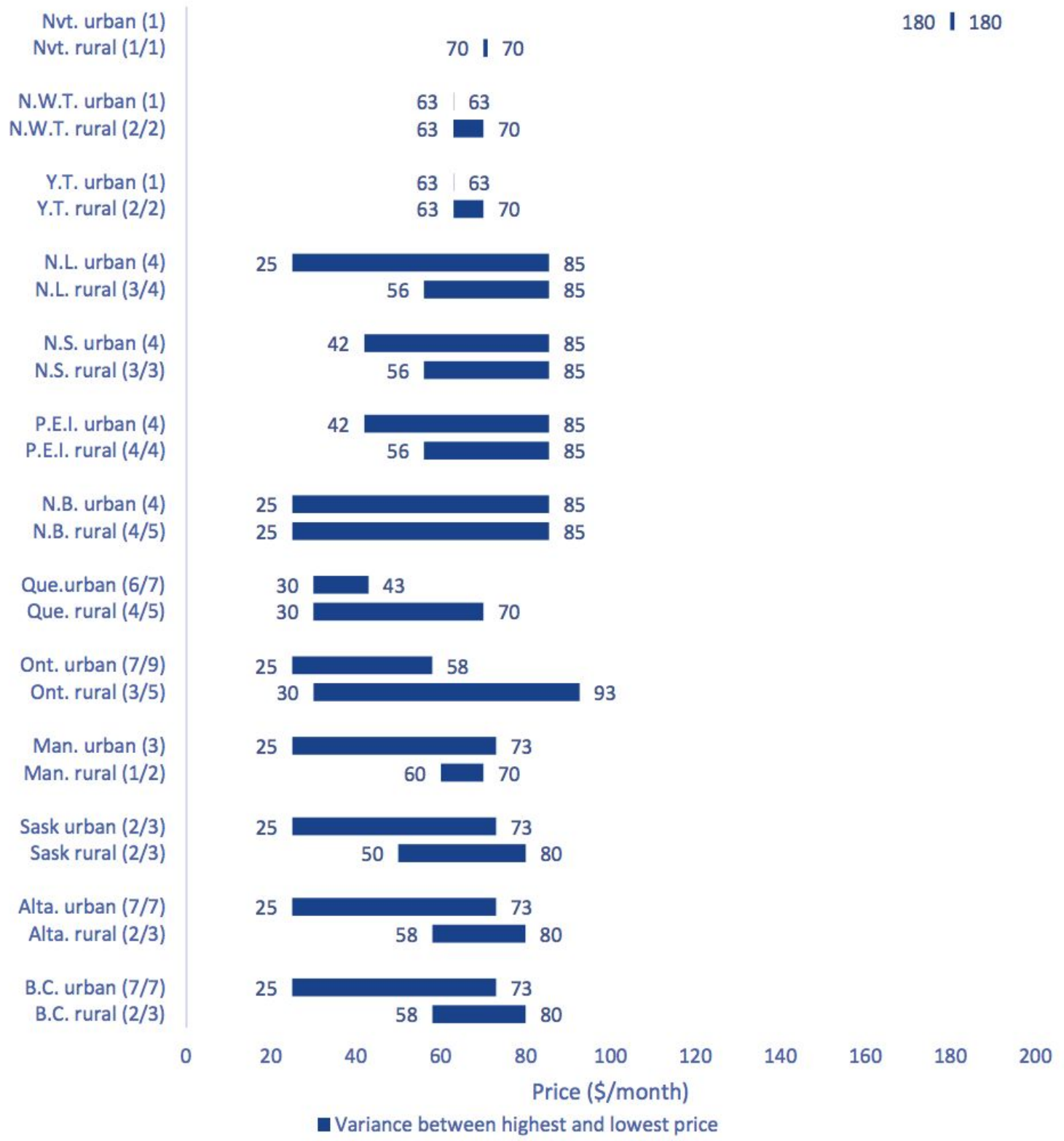

Figure 4 (CRTC 2016b) 
A family's financial capacity plays a significant role in whether it subscribes to broadband, both mobile and fixed. Despite growth in subscriptions between 2012 and 2014, 67.4 per cent of families in the lowest income quintile in Canada subscribed to mobile wireless services and 63.5 percent have use of the internet from home, as shown in Figures 5 and 6, compared to $95 \%$ and $98.3 \%$ respectively for those in the highest income quintile.

\begin{tabular}{c|ccc|ccc}
\hline \multirow{2}{*}{ Service } & Year & $\begin{array}{c}\text { First } \\
\text { quintile }\end{array}$ & $\begin{array}{c}\text { Second } \\
\text { quintile }\end{array}$ & $\begin{array}{c}\text { Third } \\
\text { quintile }\end{array}$ & $\begin{array}{c}\text { Fourth } \\
\text { quintile }\end{array}$ & $\begin{array}{c}\text { Fifth } \\
\text { quintile }\end{array}$ \\
\hline \multirow{2}{*}{$\begin{array}{c}\text { Mobile } \\
\text { wireless }\end{array}$} & 2012 & 61.7 & 75.1 & 85.9 & 91.0 & 93.4 \\
\cline { 2 - 7 } & 2013 & 66.8 & 79.7 & 88.5 & 92.9 & 96.4 \\
\cline { 2 - 7 } & $\begin{array}{c}\text { Growth 2013- } \\
2014(\%)\end{array}$ & 0.9 & 8.4 & 1.0 & 0.3 & -1.5 \\
\hline
\end{tabular}

Figure 5 (CRTC 2016b)

\begin{tabular}{c|cccccccc} 
Technology & Year & $\begin{array}{c}\text { First } \\
\text { quintile }\end{array}$ & $\begin{array}{c}\text { Second } \\
\text { quintile }\end{array}$ & $\begin{array}{c}\text { Third } \\
\text { quintile }\end{array}$ & $\begin{array}{c}\text { Fourth } \\
\text { quintile }\end{array}$ & $\begin{array}{c}\text { Fifth } \\
\text { quintile }\end{array}$ & $\begin{array}{c}\text { Average for all } \\
\text { quintiles }\end{array}$ \\
\hline \multirow{3}{*}{ Home computer } & 2013 & 64.4 & 80.6 & 89.8 & 95.4 & 97.9 & 85.6 \\
\cline { 2 - 8 } & 2014 & 64.3 & 78.1 & 87.7 & 94.0 & 97.4 & 84.3 \\
\hline \multirow{2}{*}{$\begin{array}{c}\text { Internet use } \\
\text { from home }\end{array}$} & Growth (\%) & -0.2 & -3.1 & -2.3 & -1.5 & -0.5 & -1.5 \\
\cline { 2 - 8 } & 2013 & 59.7 & 77.6 & 89.0 & 94.9 & 98.4 & 83.9 \\
\cline { 2 - 8 } & Growth (\%) & 63.5 & 78.5 & 88.7 & 95.5 & 98.3 & 84.9 \\
\hline
\end{tabular}

Figure 6 (

Finally, as a result, there's a visible divide among Canadians who not only lack access to broadband, both mobile and fixed, but also have a weak grasp of basic digital literacy 
skills needed to work in the digital economy. In 2013, Statistics Canada released a report detailing digital literacy levels in Canada. In essence, it tested Canadians' ability to access and interpret information in a digital environment. While Canada scored on par with the OECD average, the divide between digitally 'literate' and 'illiterate' in Canada is stark. Canada has a higher proportion of its population at the highest and lowest levels of literacy than any other OECD country, suggesting a vast national divide (Statistics Canada 2013). Geographic divides also exist, as Newfoundland \& Labrador and Nunavut both scored well below the OECD average (Statistics Canada 2013). Figure 7 shows each province's PS-TRE scores, a measure of digital problem-solving skills, compared to other OECD nations in the world. 
Chart 1.6

PS-TRE - Proficiency levels of population aged 16 to 65, countries, provinces and territories, 2012

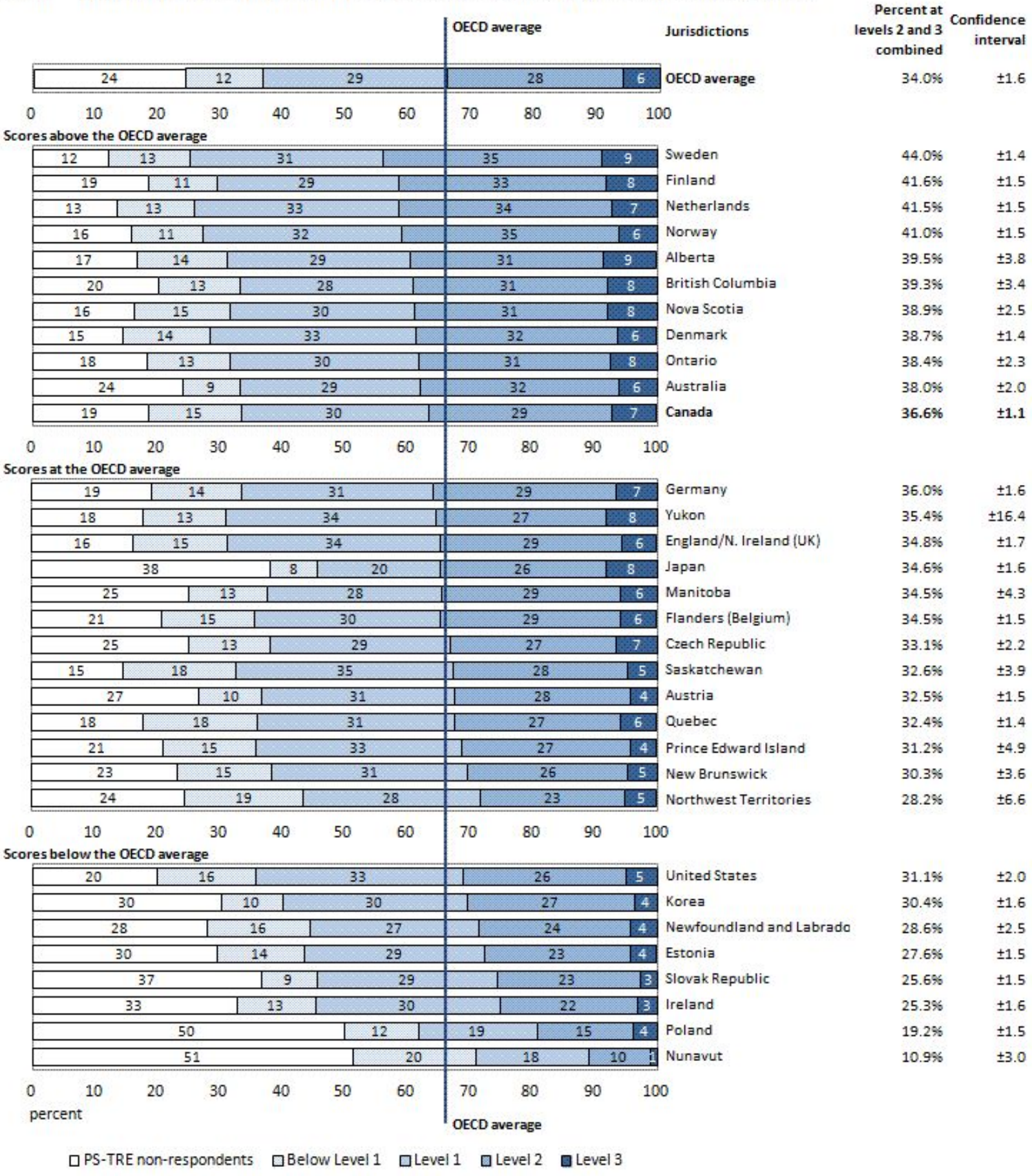

Notes: Countries, provinces and territories are ranked in descending order of adults at Level 2 and 3 for each panel of the figure. Cyprus, Italy, and Spain did not participate in PS-TRE.

Source: Programme for the International Assessment of Adult Competencies, 2012. See Table B.1.6. 


\section{Figure 7 (Statistics Canada 2015)}

While available and affordable access to broadband is necessary, addressing knowledge gaps between digitally literate and illiterate is just as important. Supporting digital literacy extends beyond having the ability to access information and services online, it also means having technical skills to solve problems encountered in a digital work environment. For graphic designers and other creatives, it means being able to navigate the gig economy. For brick-and-mortar retailers, it means leveraging tools to bring their businesses online. For farmers, it means using new tech to heighten yield and efficiency. Google estimates (2017), as new technologies evolve, more than a third of jobs are likely to require skills that are uncommon in today's workforce.

Emerging technologies and innovations are drivers for productivity and growth in almost every facet of Canada's economy (ICTC 2016). Within the next three-to-five years, the Internet of Things will change how transportation, financial services, health and social care, retail, creative services, manufacturing and beyond operate (United Kingdom, Department for Culture and Sport 2017). Many of these technologies will likely run on the 5th generation of mobile wireless networks, which are expected to leverage existing $4 \mathrm{G}$ networks and ongoing development of fixed line network infrastructure, in the form of hundreds of thousands of small cell radios with short-range, high-speed connectivity (UK 2017a 9). According to ISED (Innovation, Science and Economic Development 2016), disruptive technologies are estimated to make a $\$ 14$ \$33USD trillion impact in the global economy by 2025 . 
There is a need to develop a workforce that is capable of leveraging emerging technology and infrastructure. According to ICTC (2016), skills mismatch is not a minor problem in Canada. ICTC estimated that poor digital skills slash an organisation's productivity by 21.3 per cent (ICTC 2016). According to The Conference Board of Canada (2016), Ontario loses $\$ 24$ billion annually in gross domestic product due to skills deficits. Beyond Canada, the Boston Consulting Group (2013) revealed digitally literate small-medium sized enterprises are capable of creating twice as many jobs and realise revenue growth 15 per cent faster than those who use less.

In summary, Canada's digital divide reinforces steep socio-economic divides. Gaps in the availability of broadband services marginalize Canadians living in rural and remote areas. Furthermore, the vast range in pricing places an additional barrier for lower-income Canadians to overcome. Finally, the above mentioned issues may also give rise to a steep knowledge gap, which limits Canadians' ability to participate in the digital economy. All of these issues may be a product of allowing the free market to dictate telecommunications policy in Canada, which has been the case since the early 1990s. 


\section{Evolution of Broadband Policy and Forbearance in Canada}

Canadian telecommunications policy began a formative change in the early 1990s. Most notably, the 1993 Telecommunications Act came into effect, which has served as the bedrock of telecom policy in Canada ever since. The Act promoted the "ownership and control of Canadian carriers by Canadians and encourage[d]s the use of Canadians transmission facilities" (Telecommunications Act - S.C. 1993, c. 38 (Section 7). Furthermore, it placed an "increased reliance on market forces for the provision of telecommunications services" and to ensure "regulation, where required, is efficient and effective." (Telecommunications Act - S.C. 1993, c. 38 (Section 7). In essence, policy makers transferred substantial control of Canada's telecommunications sector to the free market and its major domestic incumbent players.

As a result, the CRTC (an administrative tribunal with responsibility for regulating Canada's telecommunication system to ensure Canadians have access to world-class telecommunications services) forbears from regulating telecommunications services that it considers to be 'competitive', including retail rates for fixed and wireless broadband services. While it's common for countries to rely on market forces to influence policy and reach objectives, the provisions set out by The Act, and subsequent decisions after, have manifested into a 'laissez-faire' approach that does not deliver highly competitive options to Canadians (van Gorp, \& Middleton 2010).

The irony behind Canada's reliance on the free market is the country's strict restrictions on foreign ownership. In Canada, foreign entities generally cannot hold more 
than 46.7 per cent of voting shares in any telecommunications service provider (Mobile Syrup 2016). However, the government does allow foreign ownership of smaller companies, those with less than 10 per cent of market share, but this provision has not resulted in any significant investment to date (Mobile Syrup 2016). To further understand how this approach has shaped Canada's telecommunications landscape, it helps to review the history of both fixed broadband and mobile broadband policy development.

\section{Mobile Wireless Services}

Spectrum is the lifeblood of the mobile wireless service industry. It serves as the invisible link between cellphone towers and devices when delivering voice, text and data services. Spectrum is also considered a natural resource and is regulated by the federal government. The development of spectrum policy in Canada offers one narrative for how Canada transitioned to a 'laissez-faire' approach from a more hands-on style.

In the early 80 s, the Department of Communications evaluated applications from telecommunications providers for spectrum based on their merit, which involved evaluating business plans, deployment of technology, services and social and economic benefit to the country (Taylor 2013128 - 131). This approach is referred to as the "beauty pageant" method of assigning spectrum to telecommunications companies.

Through this process in 1985, Rogers Cantel Inc. acquired licenses to compete with the telephone companies to provide cell service in Canada, marking the beginning 
of a transformative time for the telecommunications industry. At the time, Canada's approach to spectrum management was a point of pride. In 1986, the Department of Communications published a brochure outlining the success of its system, stating:

"Canada's telecommunications system is one of the finest in the world, providing high-quality, inexpensive and reliable services for the entire population," which they attributed to Canada being a world leader in managing frequency and spectrum (Taylor $2013128-131)$

However, market-based approaches began to steal the spotlight. Internationally, the first spectrum auctions took place in the late 1980s (McMillan 1994), and the auction approach quickly gained supporters for its efficiency and ability to generate revenue for government coffers.

In 1990, the Department of Communications launched an investigation into evolving frameworks for allocating spectrum. (Taylor 2013). In 1992, A Spectrum Policy Framework for Canada recognised the growing demand for the resource but concluded Canada ought to continue to award spectrum based on the merits of proposals, rather than awarding spectrum to the highest bidder (Department of Communications, 1992, p. 2). The document also evaluated market-based allocation approaches:

For competitive licensing, where the available spectrum is inadequate to satisfy all demands or where it is necessary to limit the number of new entrants, the Department will continue to refine its current approach-the administrative comparative process, which is used to select licensees from a number of qualified applicants. If other market-based approaches are deemed to be in the public interest and applicable to specific services or frequency bands, they will be implemented only after a full public consultation. (Department of Communications, 1992, p. 18). 
In 1993, the federal government shut down the Department of Communications and transferred the responsibility for spectrum management to Industry Canada (Taylor 2013).

In the US, support for the liberalisation of telecommunications policy gained momentum, as well. The Clinton administration gave the FCC the right to sell spectrum, through the 1993 Budget Act, providing the US with a sudden influx of cash. The FCC also viewed spectrum auctions as the best way to value the natural resource (Foosaner 2016).

It took Canada a bit longer to take the plunge. In 1995, Industry Canada introduced a spectrum cap to allow for new entrants to enter that space, while also employing an administrative approach to evaluate proposals. Clearnet PCS and Microcell Networks entered the fray, while Rogers and other incumbents also acquired spectrum on the $2 \mathrm{GHz}$ band. Both new entrants died off quickly however as Telus purchased Clearnet in 1999 and Rogers bought Microcell in 2004.

In 1996, Industry Canada released another report reviewing its spectrum allocation policy. The Review of the Comparative Selection and Radio Licensing Process concluded it would be in the public interest to shift to competitive bidding where "reliance on market forces was appropriate." (Taylor 2013). In 1999, Canada announced it would auction $40 \mathrm{Mhz}$ of PCS frequencies, paving the way for Canada's first spectrum auction held in 2001. 
Liberalisation continued with the Harper government, which reinforced the role of the free market as recommended by the 2006 Telecommunications Policy Review. (Canada Telecommunications Policy Review Panel, 2006, Recommendations 5-9). Acting on the advice of the Minister of Industry, the Governor in Council (the Governor General) directed the CRTC to:

1. Rely on market forces to the maximum extent feasible as the mean of achieving telecommunication policy objectives, and

2. When relying on regulation, use measures that are efficient and proportionate to their purpose and that interfere with the operation of competitive market forces to the minimum extent necessary to meet policy objectives. (Governor in Council 2006)

As noted in the accompanying Regulatory Impact Analysis Statement (Canada, 2006), the purpose of this direction was to provide the CRTC with specific criteria to use in assessing new regulatory measures and to encourage it to adopt operational practices to allow it to be more efficient and timely when developing regulations.

The 2007 Spectrum Policy Framework echoed the reliance on market forces, stating auctioning off spectrum is the best way to "maximize the economic and social benefits that Canadians derive from the use of the radio frequency spectrum resource (Mewhort \& Anderson 2012). 
In 2008, the Advanced Wireless Services spectrum auction raised $\$ 4.8$ billion for the Canadian treasury, while the $700 \mathrm{MHz}$ auction in the United States generated $\$ 19$ billion in revenue for the federal government.

While on one side selling spectrum provides tremendous returns for states, it also pushes sound communications policy to the side. Scholar Eli Noam argued market-based approaches are "...conceived on the original sin of budget politics rather than communications policy" and thus "spectrum auctions are doomed to serve as collection tools first and allocations mechanisms second" (Noam, 1998, p. 773. ). For Canada, while taking a market based approach has led to increased efficiency and additional revenue, it has also allowed the biggest players to grasp a strangle hold of the mobile wireless market. BCE, Rogers and Telus own more than 90 per cent of Canada's wireless market (CRTC, 2016b). As argued by others (Winseck 2014, Middleton 2011), Canada's market lacks competition, which allows little disruption, price competition, and less incentive to innovate.

Access to affordable mobile wireless service is becoming an increasingly important ingredient to closing closing Canada's digital divide. Mobile data consumption is snowballing and may even become a potential alternative to fixed telecommunications services, at the very least in areas with low population density or rural areas, where building fixed-infrastructures may not make business sense (EU 2016). While LTE infrastructure, the fourth-generation of mobile wireless broadband technology, covers 99 per cent of households, gaps in speed and affordability relative to 
fixed-broadband persist (CRTC 2016b). Following a 2012 decision that declared that the market for wireless services in Canada was competitive and did not require rate regulation (CRTC 2012), the CRTC has favoured approaches which aim to make the market more 'dynamic' and empower consumers.

In 2013, the CRTC introduced The Wireless Code of Conduct, a set of standards designed to empower consumers and contribute to creating a more dynamic market for wireless service providers (CRTC 2013). Key provisions in the code included a cap on the duration of post-paid service agreements and standards for contracts to ensure clarity (CRTC 2013). In 2017, the CRTC reviewed and amended the code to eliminate 'device unlocking' fees, which keep consumers tied to their providers (CRTC 2017c). The FCC (2003), Ofcom (2003), TIO (2012) and others developed nations have introduced similar codes. The code has been successfully adopted by wireless service providers in Canada (CRTC 2014) and has standardised wireless service agreements across the country. However, it has not made the market more 'dynamic', as shown by declining churn rates since its introduction in 2013 (CRTC, 2016b).

As noted above, the government has also attempted to foster competition by setting aside spectrum for new entrants, or capping the amount of spectrum available for incumbents (Industry Canada 2007b, Industry Canada 2012). However few new entrants have been successful, and none compete in all markets across the country. The non-incumbent new entrants from the 2008 AWS auction (WIND, Mobilicity, Public Mobile) have been acquired by an incumbent, and other new entrants (Vidéotron, 
Bragg) only compete regionally. Only WIND (now rebranded as Freedom Mobile) has built out a network in multiple provinces.

Most recently, the CRTC's BTS (Basic Telecommunications Services) decision in December 2016 declared mobile services to be essential. The decision calls for high service availability objectives, one of which is to ensure availability of "the latest generally deployed mobile wireless technology....in Canadian homes and businesses... [and] many major transportation roads as possible in Canada" (CRTC 2016a). To support this goal, the CRTC also announced it would allocate a portion of its $\$ 750$ million broadband fund to the development of mobile wireless infrastructure. While it marks the first effort to fund mobile broadband infrastructure on a federal level, the announcement of Canada's fund comes years after several other developed nations have pushed their funds.

Other countries have been more aggressive to support the penetration of mobile wireless broadband, through public/private initiatives and regulations supporting service-based competition. The creation of Broadband Delivery UK in 2010 signalled a strong step from the United Kingdom to combat inequalities created by the market. Through this fund, the UK government supported the development of mobile and fixed broadband infrastructure in rural areas. It dedicated 150 million pounds, out of the fund's total allocation of 780 million, to the development of mobile wireless infrastructure as of June 2013 (Ashmore et al. 2015). 
Going one step further, it also announced a strategy for the deployment and provision of the next generation of mobile wireless technology, 5G (UK 2017a). In its plan, entitled Next Generation Mobile Technologies: A 5G Strategy for the UK, the government outlined funding programs to test applications for the next wave of mobile development (UK 2017a). Also, the UK announced its Digital Infrastructure Fund, which pegs 400 million pounds for public/private partnerships to accelerate the deployment of fibre (UK 2017a). The Canadian government has acknowledged the importance of 5G, and has solicited public comment on how to manage spectrum for a $5 \mathrm{G}$ rollout in Canada, but no course of action has been planned out to date (Innovation, Science and Economic Development Canada 2017).

In 2011, the FCC committed to providing fixed and mobile broadband in high-cost areas of the United States that the marketplace would not otherwise serve (FCC 2017). As a part of the Connect America Fund, Mobility Fund Phase 1 offered $\$ 300$ million of support, resulting in the deployment of $3 G$ or better service in areas covering more than 85,000 US road miles not previously served. The plan also pledged an additional 50 million dollars to tribal lands, which supported projects covering 56,932 people in 80 biddable areas (FCC 2017).

In April 2014, the FCC announced Phase 2 of the mobility fund would target areas of the country without $4 G$. With a USD 4.53 billion budget over ten years, the FCC will offer support to areas lacking mobile voice and data services. Similar to Phase One, the FCC will employ a reverse auction to prioritise and allocate funds. 


\section{Fixed Broadband Market Interventions}

Canadian policy makers have also been reluctant to intervene in the fixed broadband space. Public actors fear heavier regulation will reduce capital investment in network infrastructure by the major incumbents (see for example the submissions to the 2013 CRTC consultation on wholesale access, which led to CRTC policy 2015-326).

However, investing in network infrastructure is a primary driver of growth for any facilities-based telecommunications firm. Despite heavier regulation, telcos may still be motivated to spend, which former CRTC Chairman J.P. Blais noted:

"Companies came to our hearing and advocated that we should not have unbundling of fibre. They were saying it would slow down investment; they would not go forth as much, it was different from the mandatory access we had given in the past. It was a new brave world; they weren't incumbents. A whole series of arguments. In the end, we decided we were going to mandate unbundling even on fibre. They went to the federal cabinet to appeal it. The federal cabinet did not intervene....

Oddly enough, as they were saying one thing to us about slowing down investments, they were having a completely different dialogue with the investors and saying quite the opposite. I don't know what they think we read and don't read, but l've got some very, very smart people working for me at the CRTC and we read investor reports, we read what's in the news, we know what's happening. So it goes straight to credibility when you make arguments in front of us one day and take a completely different position when you're on an investor or shareholder call." (J.P. Blais 2017)

While overall capital expenditure has been shown to decline in markets with regulations promoting service-based competition (which encourages network sharing through wholesale access), nations which have strong wholesale regulations tend to 
perform better in connectivity speeds and penetration of fibre-to-the-premise, as noted by Rajabiun \& Middleton $(2017,217)$, who also stated

However, forbearance from mandated wholesale access has not been effective in promoting FTTP deployment incentives, and network outcomes in terms of measured speeds in North America remain at about the EU average. The apparent gap between investment inputs and network outcomes suggests infrastructure competition among legacy network operators may not be a very efficient arrangement for promoting innovation and creative destruction in the transition from sunset to sunrise technologies. (Rajabiun \& Middleton 2017, 225)

In essence, passive government approaches do not necessarily result in the best outcomes regarding network performance. While urban areas reap the benefits of innovative services, rural areas become further isolated and marginalised (Nokia 2015). Less competition creates less downward pressure on prices, leaving affordability gaps, which in part created chasms between the economic classes concerning access.

This isn't to say Canada has not intervened in the market or provided programs to narrow Canada's digital divide, but it has not been to the same level as some other developed nations. In the early-2000s, the federal government realised rural and remote communities were being underserved (Rajabiun \& Middleton 2013, 12). In response, Canada deployed a series of piecemeal interventions and regulations. In 2001, the National Broadband Task Force proposed a multi-billion public investment for broadband to be available to every business and household (National Broadband Task Force 2001). However, it didn't garner enough support. Instead, other smaller, piecemeal initiatives were adopted. The Broadband and Rural Northern Development (BRAND) program operated from 2002 - 2007 and provided \$84 million in matching funding to communities to deploy broadband in underserved areas (Industry Canada 
2007). BRAND aided 217 projects (Industry Canada 2007). In 2010, the CRTC also allowed incumbents to use funds in "deferral accounts...to expand broadband services to 112 communities in Ontario and Quebec (CRTC 2010). In essence, it allowed incumbents to retain funds it overcharged to its customers but only under the condition it reinvested the funds into network infrastructure, in turn spawning deeper facilities-based competition. Broadband Canada: Connecting Rural Canadians provided $\$ 200$ million to cover up to half the fixed costs of extending broadband network coverage around 215,000 rural householders without prior access (Industry Canada 2010). Industry Canada also funded other initiatives through the Canada Strategic Infrastructure Fund, which involved a bottom-up approach by engaging lower levels of government, not-for-profit organisations and the private sector (Infrastructure Canada 2017) Between 2002 and 2013, subsidies for fixed-broadband infrastructure totalled $\$ 1$ billion to various entities, a far cry from the $\$ 4$ billion recommended by the NBTF. (Rajabiun \& Middleton 2013, 13). In 2014, the government announced an additional $\$ 305$ million to extend fixed-broadband to 280,000 households in rural and remote areas of the country through the Connecting Canadians program (Industry Canada 2015). The Liberals have since adopted the program and have expanded funding through the "Connect to Innovate" program (ISED 2017b). In its December 2016 basic services decision, the CRTC announced a $\$ 750$ million fund for the development of both fixed and mobile broadband infrastructure, but it's not clear when the fund will be fully functional or how the funds will be deployed (CRTC 2016a). While the public sector is 
starting to pick up steam and narrowing the gaps in coverage between rural and urban communities, BDO Canada estimated it would take $\$ 40$ to $\$ 60$ billion to connect the entire country to fibre optic networks (BDO Canada 2017).

To support competition at the retail level, the CRTC also mandated wholesale rates for access to fixed broadband infrastructure, including fibre optic infrastructure. These regulations allow competitors who have not built their own facilities, such as Teksavvy, to enter the market, through what is known as service-based competition. Without wholesale access, fewer competitive and affordable service options would be available (CRTC 2015).

Provincial governments have also stepped in to fund or incentivise fixed-broadband projects. Alberta invested more than $\$ 190$ million in the Alberta Supernet, a network connecting 4200 public institutions, including schools, libraries, hospitals and other facilities (Hampel 2016). British Columbia took another approach by leveraging its buying power with Telus. Under the Connecting British Columbia Agreement, Telus agreed to upgrade network facilities and improve rural broadband speeds in return for a ten-year procurement contract with Telus, covering a full gamut of telecommunications systems. Also, BC also offered grants to non-incumbent service providers to build last-mile connectivity through the Community Network Infrastructure Grant Program (Rajabiun \& Middleton 2013).

In 2016, the CRTC announced goals for promoting fixed broadband coverage with a minimum of $50 \mathrm{Mbps}$ down and $10 \mathrm{mbps}$ up. While these speeds are enough for 
the average Canadians' internet usage habits, it's easy to envision a future where bandwidth constraints could become an issue with the evolution of the Internet of Things, autonomous vehicles, and other connective technology. Deploying fibre, which operators are currently configuring to offer speeds up to $1 \mathrm{Gbps}$ but can be upgraded to much higher speeds over time, could 'future proof' Canada's infrastructure.

"A vision for the next generation broadband poses the question as to whether the technologically neutral stance that generally guides policymaking should be set aside to actively advance the deployment of fibre... A fibre connection means bandwidth targets can be more aggressive and scale as users need demand..." (BDO 7 Middleton. 2016)

In Canada, fibre-to-the-premise (FTTP) penetration is lower than the OECD average. Canada sits at 10 per cent, while the average is 17.9 per cent (OECD 2015). The European Commission believes "fibre is the next step in the natural, technological evolution of the fixed-line telecommunications industry and is essential to meeting the ambitious broadband targets set out in the Digital Agenda" (EU 2016b).

Sweden is a shining example of connectivity, with high penetration rates, despite harsh geographical conditions, with a dispersed population (EU 2016). At the start of 2015, fibre connected 40 per cent of all fixed-broadband subscriptions in Sweden (EU 2016). The Swedish government uses various funding mechanisms to finance broadband infrastructure projects (EU 2016). In the late 1990s, the City of Stockholm established a holding company, Stokab, that only used $€ 5,500$ in public funds. The rest of its funding came from bank loans and revenues from leasing its fibre network (EU 2014, 23). Today, all businesses and 95 per cent of residents in Stockholm are 
connected to fibre. Elsewhere in Sweden, 160 other municipalities have followed a similar model, which has helped fibre-networks reach 70 per cent of residents (EU 2016). Through its national broadband strategy, Sweden has also committed to making $1 \mathrm{Gbit} / \mathrm{s}$ speeds available for 98 per cent of homes and businesses. The remaining 1.9 per cent of households should have access to minimum capacity of $100 \mathrm{MB} / \mathrm{s}$ and 0.1 per cent should have access to a minimum capacity of 30 Mbps. (Sweden 2015,6) The municipal network model is common in Nordic countries and has led to successful deployments regarding coverage, penetration, competition and financial sustainability (EU 2016).

As a way of implementing its broadband strategy, France Très Haut Débit, Axione Infrastructure and the European Investment Bank have issued 'project bonds' to attract private capital investment into fibre-optic in sparsely populated areas (EU 2016). In Italy, ENEL, its leading energy company, has made its infrastructure available to deploy fibre in areas 'at risk of digital divide.' (EU 2016)

Worthy of mention, but now less ambitious, Australia's National Broadband Network would have extended fibre-to-the-premises to 93 per cent of Australian households. The remaining seven per cent of Australians would have been linked by fixed wireless or satellite technology. The Labor Party introduced the project in 2009 and estimated the project would cost AUD $\$ 43$ billion. While the cost would have been massive, a Deloitte study (2013) estimated the project would have provided savings and job opportunities worth $\$ 3,800$ AU per household per year by 2020 . 
After the 2013 election in Australia, a coalition of conservative parties reduced speed and coverage goals to $25 \mathrm{Mbps}$ down and only set requirements to deploy fibre-to-the-premise to new housing projects. For remaining residents and businesses, NBN would bring fibre-to-the-node, with the last mile being connectivity being offered with copper (Tucker 2013).

\section{The impact of the free market}

Why does it matter that the free market is Canada's primary tool for achieving broadband delivery objectives? By its nature, the free market breeds inequality. It is driven to service areas and demographics which will provide the largest, short-term return on investment. Actors in the free market are not out for ubiquitous social welfare; they are out for profit. In this context, it results in the uneven development, particularly in rural, remote and poorer areas of the country, as shown in the previous sections. A quick look abroad and in Canada reveals a few likely scenarios when the market is left to its own devices.

The number of telecommunications providers may shrink without intervention. For example in the United States, mobile carriers T-Mobile and AT\&T would have merged if it weren't for a challenge by the Department of Justice in the United States (The United States Department of Justice 2011). Today, T-Mobile continues to push boundaries with their aggressive pricing strategies and offerings, including unlimited data plans, which are the equivalent to unicorns in Canada. Meanwhile, in the UK, 
Ofcom allowed Three and $\mathrm{O} 2$ to merge, but only after it forced the resulting firm, Everything Everywhere Mobile, to divest a quarter of its LTE spectrum holdings to strengthen a new fourth carrier, Hutchison 3G. In short, both countries assured their markets sustained some degree of competition.

Canada's market continues to consolidate. In March 2017, the Competition Bureau allowed Bell to acquire MTS, a regional facilities-based telecommunications provider. While approval of the deal did involve divesting assets to Xplornet, a rurally based service provider, it is yet to be seen if the concessions made will yield a net benefit to consumers (Geist 2017).

Proponents of consolidation argue it leads to economies of scale and more investment in network infrastructure. However, there is no guarantee that profits will be reinvested into infrastructure (EU 2016a). Consolidation rarely results in the development of infrastructure in rural areas and does not drive down price (EU 2016a). Since the turn of the century, Canada's telecommunications providers have operated with significant market power, in large part due to the CRTC's hands off approach, which has been guided by the direction set out the 2006 Telecommunications Policy Review. Furthermore, it has been exacerbated by the federal government's reluctance to slow down consolidation, as demonstrated by its decision to allow MTS to merge with Bell. As Canada's market continues to consolidate, it has systematically created a situation that has given major incumbents substantial market power, resulting in less selection for consumers, resulting in less price competition and in turn, spawning not 
only affordability but also availability issues, two key drivers behind Canada's digital divide. Figure 8 shows Canadians, on average, only have a choice between two service

Wireless service coverage by number of facilities-based WSPs, 2015

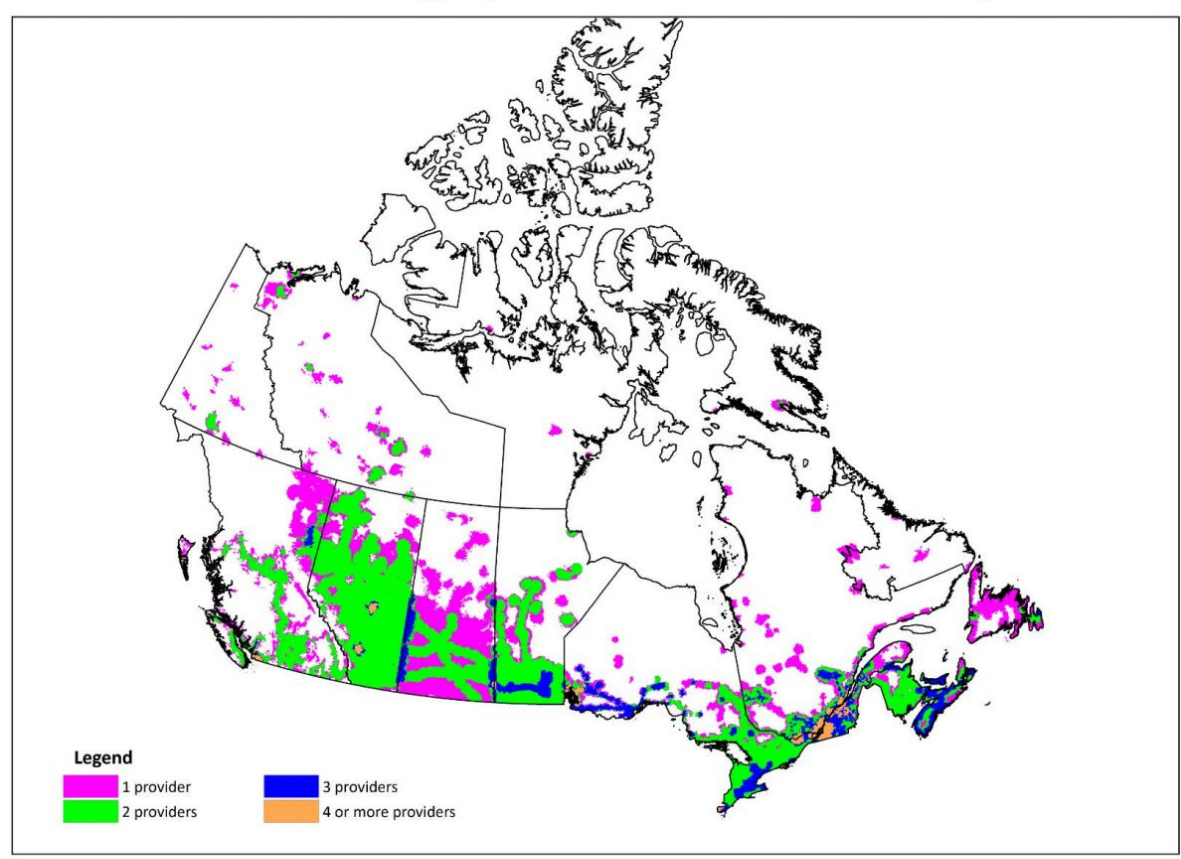

Source: CRTC data collection

providers.

This map shows the cross-country availability of wireless services from facilities-based WSPs.

Figure 8 ( $\underline{\text { CRTC 2016b) }}$

Meanwhile, countries that have actively encouraged competition have realised higher rates of penetration (EU 2016). The lesson for Canada is it doesn't need to be a passive player, and can do more to ensure that market competition delivers desired outcomes.

\section{Cracking The Digital Literacy Issue: Canada \& Abroad}


Canada also runs the risk of widening its digital divide if it builds infrastructure but does not teach Canadians how to leverage connectivity (Colledge \& Haight 2016). As Colledge and Haight explain (2016), 'digital literacy, or lack thereof, has the potential to create a new type of inequality between those 'who know' and those 'who don't know' how to be full participants in the digital world." Belloc et. al (2012) reinforced this idea when they revealed once broadband connectivity is available in a given area, using demand-side strategies, including digital literacy training, are more effective in increasing broadband penetration than building further infrastructure.

While the average Canadian's digital literacy skills are above the OECD average, the largest portions of its population are at either the highest or lowest levels of literacy, illustrating a stark divide (Statistics Canada 2015). Similar to broadband availability, digital literacy levels also vary between provinces.

In its December 2016 basic service decision, the CRTC sidestepped responsibility for tackling this issue alone when the Commission stated "other parties are better placed to implement solutions to address the gaps in digital literacy" in its submission for the Innovation Agenda (CRTC 2016c). While the CRTC cannot shoulder the entire load for formulating a digital literacy strategy, it will be well positioned to take on a substantial advisory role, as it rolls out its $\$ 750$ million Broadband Fund. Although the CRTC does not have a history in developing skills training, the information collected and used to devise the Broadband Fund will go hand-in-hand with where to target digital 
literacy programs, which currently lack consistency throughout the country (MediaSmarts 2015).

Within the 2017 federal budget, the Liberal government pledged $\$ 50$ million in funding over two years for a competitive fund to support NGOs providing digital literacy training for elementary and secondary school students (Government of Canada 2017). The budget also included a $\$ 29.5$ million fund over the next five years for NGOs with programs offering training for vulnerable groups, such as low-income individuals and families and seniors. Again, while these funds are commendable, the federal government does not have to be a passive figure, a role it has relegated itself into by acting only as a financier for uncoordinated training programs. Canada's public sector can be more active, simply by creating a national digital literacy strategy, similar to other developed nations (Brookfield 2017, 5). While provinces, municipalities and non-government organisations have admirably stepped in to fill this void, the structure of these initiatives varies from region to region, resulting in inconsistencies. MediaSmarts performed an audit capturing the wide array of strategies, frameworks and initiatives used to teach digital literacy. It unveiled vast differences, from how digital literacy is defined to how it's taught. The word map below shows the wide range of terminology and verbiage in policy documents and curricula around the country. 


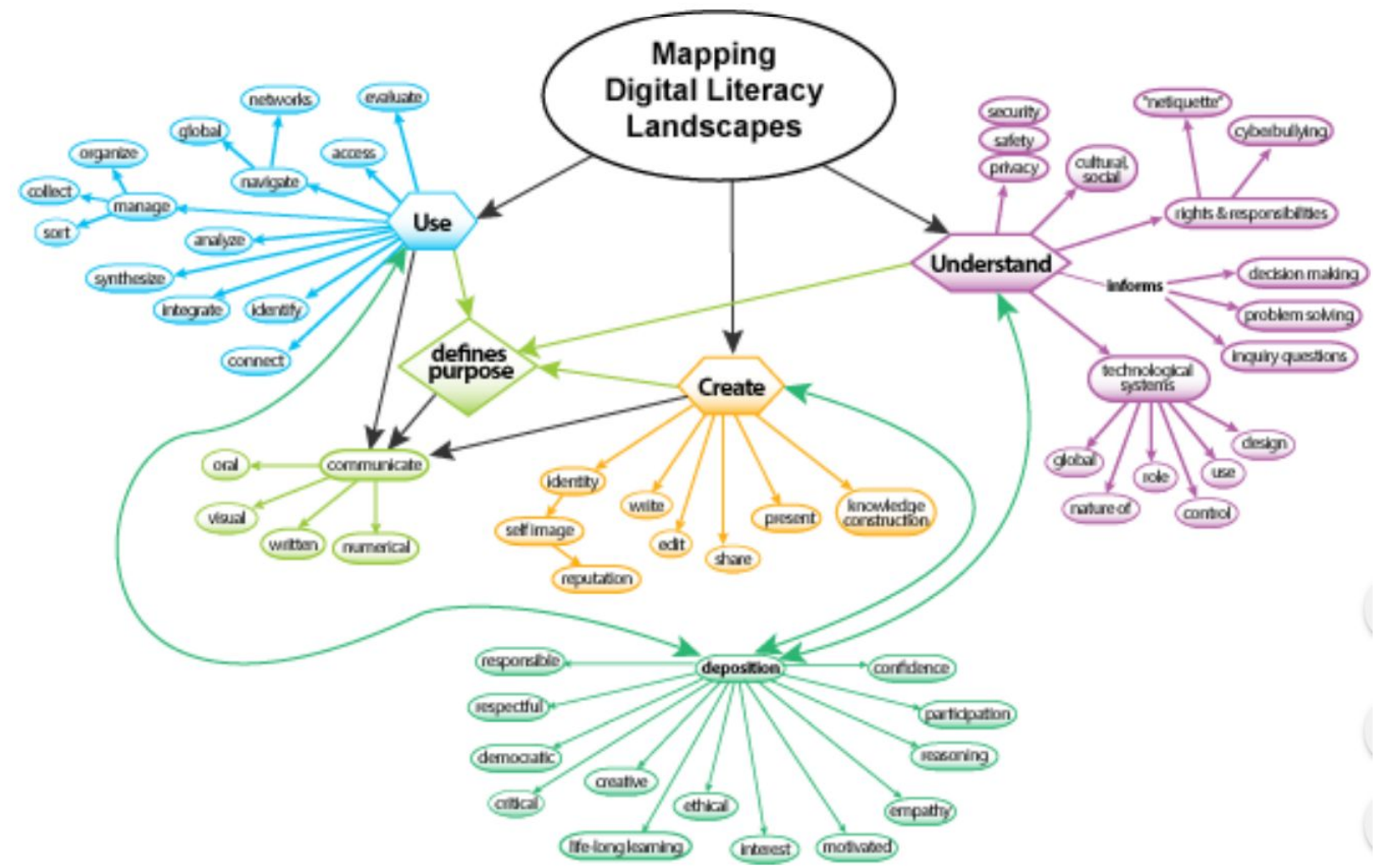

As highlighted by MediaSmarts (2015), there is no universal definition of digital literacy.

There is plenty of debate not only in Canada but also abroad. However, there is one fundamental tenet that can be found in most national literacy strategies: co-ownership of the issue (EU 2013). Co-ownership means that NGOs should not be the only players in the space taking an active role to resolve digital illiteracy, and that the private and public sectors should also be engaged (EU 2013). There are actions Canada can take to encourage a cohesive push from all levels of society, as shown abroad.

The United Kingdom took an aggressive stance on closing its digital divide when it launched its Digital Strategy, an umbrella of frameworks and tactics to tackle multiple 
levels of digital exclusion, from literacy to infrastructure (UK 2017b). The 'Digital Inclusion' portion of the strategy is a robust initiative aimed at providing access, connectivity and training to citizens of the UK. It outlines provisions to continue funding of digital skills training, which has amounted to $£ 85$ million of financing since 2014 (UK 2017b). It also has in place incentives for existing teachers to bolster their digital literacy skills through professional development programs and provides scholarships, up to $£ 27,500$, to computer science graduates to enter teacher's college.

Finally, the UK also created a council for digital inclusion, the Digital Skills Partnership, an organisation comprised of private sector and charitable organisations to coordinate with the government for the provision of digital skills training.

The EU also has a similar collective known as The Digital Skill and Job Coalition, which invites actors on all levels within Europe to participate. The EU also asked all member states to create national coalitions and digital literacy strategies by mid-2017 (EU 2017). Also, the EU goes a step further by offering member nations frameworks, supported by successful practices. By 2020 , the EU hopes to train 1 million unemployed youth through internships, apprenticeships and short term training programmes (EU 2017). Sweden followed suit in the 2017 by introducing its own Digitisation Council, which consists of representatives from both public and private bodies. The council's primary mandate involves "the creation of greater coordination between different governmental and public organisations" (Digitaliseringsrådet 2017). The United States 
may also create a collective, as the FCC recommended through its Strategies and Recommendations for Promoting Digital Inclusion report (FCC 2017).

\section{Discussion: A Framework for Canada's Innovation Agenda for Social Good}

There is still room to improve the use of policy tools to close Canada's digital divide within the confines of Canada's mandated laissez-faire approach. Without dipping a toe into the market, a solid start would be to formulate a cohesive digital strategy, which could be contained within the Innovation Agenda. As noted above, Canadians' ability develop innovative contributions to the digital economy hinges on not only having access to high-quality broadband services, but also having the ability to leverage connectivity. Furthermore, uneven regional development of network infrastructure and digital skills training may hamper the ability of underdeveloped regions to deploy new, upcoming innovations, such as the services that will operate on the Internet of Things. Therefore, the Innovation Agenda should include some semblance of a plan that aims to bring ubiquitous network coverage and skills training across the country. To maximise the impact it can have on narrowing Canada's digital divide, policy makers may be well advised to follow the lead of Sweden, United Kingdom, United States, and most European countries by formulating specific plans, which can fall under the umbrella of the Innovation Agenda as follows: 


\section{A national broadband strategy, which details mechanisms for spurring investment in both mobile and fixed broadband projects.}

A robust, cohesive national broadband strategy, which would serve as a framework for funding programs aimed at developing fixed and mobile wireless broadband in underserved areas, would help narrow network coverage gaps. Canada's broadband plan should detail the level of intervention it wishes to carry out, which is already within The Act (Telecommunications Act (S.C. 1993, c. 38). It should also include an analysis of service gaps, coverage and speed objectives, all of which have been articulated by the annual Communications Monitoring Report and the CRTC's BTS decision in 2016 (EU 2014, 11). To fully formulate a strategy, the CRTC and ISED need to decide how they want to leverage the CRTC's new broadband fund and how it will complement the government's existing Connect to Innovate program (this question is being considered in a current consultation, CRTC 2017b). There are several funding models to stimulate broadband penetration that have been discussed in this paper, a mixture of which should be used.

As considered by Belloc et al. (2012), the best approach for encouraging infrastructure development and broadband penetration is by using a blend of supply-side and demand-side policy tactics. Canada may be well served by adopting a bottom up approach, in the same vein as Sweden and other Nordic countries. BDO suggested one method of achieving this is by engaging the Federation of Canadian Municipalities and other municipal organisations, which would serve as a means to 
encourage municipal governments to develop strategic plans and invest in infrastructure development (BDO 2017, 15). These strategies should aim to deploy current and next generation infrastructure, such as fibre, 4G and 5G (BDO 2017 15). When encouraging infrastructure development, municipalities should be reminded about the return on investment for broadband. Again, going back to Stockholm, the city currently raises around $€ 20$ million in revenue per year from operators and companies using its fibre infrastructure (Belloc et al. 2012).

To supplement efforts made by municipalities, Canada should continue to foster public and private partnerships to make broadband accessible, as it has done through the BRAND and Connecting Canadians Programs. With that said, the fund should encourage private partners to exceed to allotted goals put forth by the CRTC's BTS decision and place an emphasis on 'future proofing' infrastructure. For allocating these funds, Canada can rely on reverse auctions, as used by the FCC to for its Connect America and Mobility Fund. Reverse Auctions serve as an efficient mechanism for allocating funds and evaluating the threshold of public support needed to bring private sector investment into area otherwise left barren by the free market. Simply put, facilities-based providers put forth proposals, which can be evaluated based on both economic and social benefits, for government funding to service a given area.

Finally, the CRTC may also be well advised to introduce mandated wholesale rates for mobile wireless services. A lack of mandated wholesale rates for Mobile Virtual Network Operators limits service-based competition in the Canadian market. At the time 
of writing, the CRTC had yet to mandate wholesale rates for the provision of mobile wireless services. While the CRTC has played a role in policing roaming agreements between providers, it has often had an adverse affect on service-based competition. Most recently, the CRTC ruled MVNO Sugar Mobile improperly leveraged its roaming agreement with Rogers to obtain 'permanent', rather than incidental, access to Roger's cellular network (CRTC 2017a).

The CRTC is aware of the issue, as several MVNOs have cited problems gaining a foothold in the market (CRTC 2015 - 177). The lack of competitive offerings from MVNOs results in less price competition, which has been vaguely acknowledged by Minister Navdeep Bains.

"We do still support a facilities-based competition, I made that very clear as well, but at the same time as you know we have [high] price points for consumers in Canada and middle-class Canadians are struggling, these are challenges they're facing, particularly individuals with multiple cellphone bills, multiple wireless consumers in the household." (Mobile Syrup 2017)

As a result, Baines has asked the CRTC to review its decisions against Sugar Mobile. A decision is expected by March 2018. While MVNOs often do not reinvest revenue into building facilities, service-based providers can provide increased competition in markets, which can ignite price wars and help make broadband rates more affordable, as it has in the fixed broadband space (Mewhort \& Anderson 2012).

Demand-side policies, aimed at enhancing the value of broadband adoption, should also be included in the strategy. Examples of demand side policies include moving government services online, promoting business incentives for adopting 
broadband, tax breaks for target demographics, or aggregating demand to create more incentive for development. Promoting digital literacy also falls under this category.

2. A digital literacy strategy, which maps current initiatives throughout the country, with a gap analysis and solutions for closing those gaps.

As noted above, Canada can maximise its investment in infrastructure by ensuring Canadians can effectively leverage connectivity. Formulating a national digital literacy strategy will help to narrow digital literacy discrepancies between provinces. To properly formulate this plan, ISED should seek to refine its definition of digital literacy to help establish metrics that accurately measure it. It should also seek to map out current digital literacy initiatives and extract best practices (MediaSmarts 2015). Finally, to reconcile varying interests and to create a cohesive effort, Canada should create a digital council, as done in the United Kingdom and elsewhere in Europe. This council should be comprised of NGOs, private sector and public sector actors, which have a stake in the issue.

\section{A research strategy to unveil best practices for developing NGN in} underserved areas, including $5 \mathrm{G}$ and fibre optic networks

As the demands for broadband grows, Canada should play an active role in the advancement of telecommunications research, including exploring methods of deploying necessary technology on roads, traffic signals, transit and other forms of public infrastructure on to accommodate future loT applications. Canada can look to the UK and other nations that have started similar initiatives for guidance (UK 2017b). 


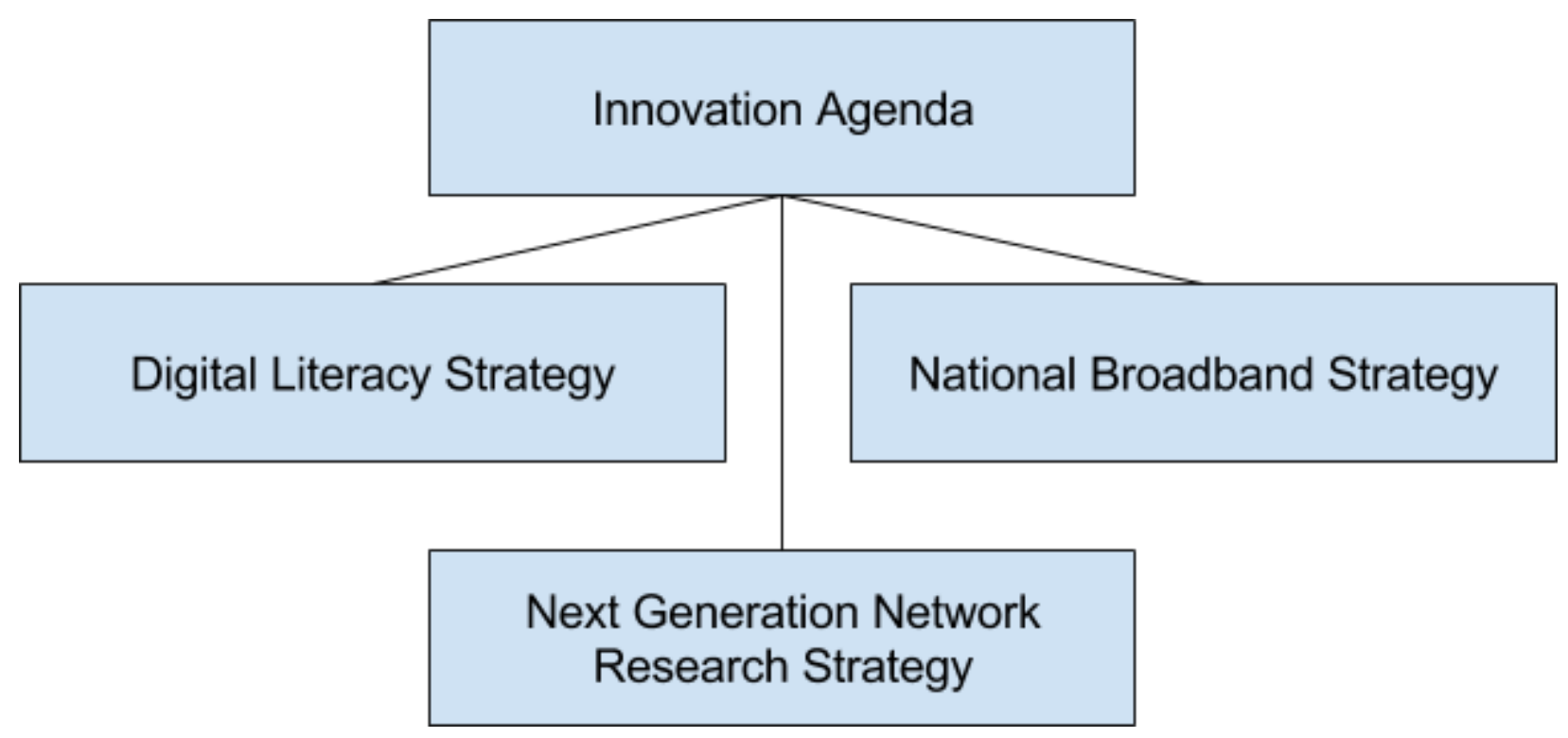

\section{Conclusion}

The CRTC and ISED need to be more creative and proactive in deploying policy, particularly when it comes to the provision of broadband. Canada stands to place itself in a better position by being active and no longer waiting for facilities-based competition to pick up the slack. This can take various forms, as noted above, including by devising national level strategies for the deployment of nationwide infrastructure and digital literacy training. Furthermore, the federal government, ISED and the CRTC may need to take more radical steps by amending the 1993 Telecommunications Act to allow public actors to devise interventions which can have a more profound effect. The system in place does render leadership sufficient power to effectively curb the negative effects of 
the free market, particularly when it comes to consolidation, as recently shown by the conditions imposed upon the MTS and Bell merger. By not playing an active role, Canada runs the risks of widening its digital divide, marginalising vulnerable members of society, and falling further behind the rest of the world in the deployment of next generation network technology.

While Canada does have unique challenges, it should not idly stand by in the deployment of broadband infrastructure. The announcement of the broadband fund is a positive step. However, the CRTC's BTS decision leaves work to be done, including determining how the fund will be utilised, ensuring networks are 'future proof' and preparing itself for the next generation of ICTs.

The CRTC and ISED can realise their goals by leveraging capital and policy tools to engage other actors. Federal policy makers should seek out and provide support to municipalities, both urban and rural, to ensure the development of broadband is within the scope of their infrastructure mandates. It should leverage funds to mobilise the incumbents and other private players to invest in underserved areas. Finally, it should engage actors on all levels to formulate a digital skills training strategy that is inclusive and sensitive to unique needs across the country. With a cohesive vision, Canada should realise a narrowing of its digital divide. 


\section{References}

Ashmore, F. H., Farrington, J. H., \& Skerratt, S. (2016). Community-led broadband in rural digital infrastructure development: Implications for resilience. Journal of Rural Studies, doi:10.1016/j.jrurstud.2016.09.004

Belloc, F., Nicita, A., \& Alessandra Rossi, M. (2012). Whither policy design for broadband penetration? evidence from 30 OECD countries. Telecommunications Policy, 36(5), 382-398. doi:10.1016/j.telpol.2011.11.023

BDO (Binder Dijker Otte) Canada (2017). Broadband: The Next Essential Utility. Retrieved September 01, 2017 from

https://www.bdo.ca/en-ca/insights/consulting/risk-advisory/broadband-the-next-essential-util ity/

Broadband: the next essential utility. (2017). Retrieved September 01, 2017, from https://www.bdo.ca/en-ca/insights/consulting/risk-advisory/broadband-the-next-essential-util ity/

Brookfield. (2017). The State of Digital Literacy in Canada. Retrieved September 01, 2017, from

http://brookfieldinstitute.ca/wp-content/uploads/2017/04/Brookfieldlnstitute_State-of-DigitalLiteracy-in-Canada_LiteratureReview.pdf

Boston Consulting Group. (2013). Lessons on Technology and Growth from Small-Business Leaders. Retried September 01, 2017, from:

https://www.bcgperspectives.com/content/articles/technology_software_globalization_ahea d_curve_lessons_technology_growth_small_business_leaders/

Canada. (2006). Regulatory Impact Analysis Statement (regarding SOR-2006-355). Retrieved from

https://www.canada.ca/en/news/archive/2006/12/canada-new-government-issues-policy-dir ection-crtc-that-calls-greater-reliance-market-forces.html

Canada. 1993. Telecommunications Act, S.C., 1993, C. 38. Ottawa: Minister of Justice.

Canadian Radio-television and Telecommunications Commission (CRTC). (2010, August 31). ARCHIVED - Follow-up to Telecom Decision 2008-1 - Proposal by Bell Aliant Regional Communications, Limited Partnership and Bell Canada to dispose of the funds remaining in their deferral account. Retrieved September 01, 2017, from

http://www.crtc.gc.ca/eng/archive/2010/2010-637.htm

Canadian Radio-television and Telecommunications Commission. (2012). Telecom Decision CRTC 2012-556: Decision on whether the conditions in the mobile wireless market have changed sufficiently to warrant Commission intervention with respect to mobile wireless 
services. Retrieved September 01, 2017 from

http://www.crtc.gc.ca/eng/archive/2012/2012-556.htm

Canadian Radio-television and Telecommunications Commission (CRTC). (2013, June 03).

The Wireless Code. Retrieved September 01, 2017, from

http://www.crtc.gc.ca/eng/archive/2013/2013-271.htm

Canadian Radio-television and Telecommunications Commission (CRTC). (2014, September 18). Wireless Code: Implementation Report Card. Retrieved September 01, 2017, from http://crtc.gc.ca/eng/publications/reports/rp140918.htm? ga=2.253945800.1743954822.15 00492414-1563419858.1495301711

Canadian Radio-television and Telecommunications Commission (CRTC). (2015, May 05). Telecom Regulatory Policy CRTC 2015-177. Retrieved September 01, 2017, from http://www.crtc.gc.ca/eng/archive/2015/2015-177.htm

Canadian Radio-television and Telecommunications Commission (CRTC). (2015, July 22). Telecom Regulatory Policy CRTC 2015-326. Retrieved September 01, 2017, from http://www.crtc.gc.ca/eng/archive/2015/2015-326.htm

Canadian Radio-television and Telecommunications Commission (CRTC). (2016a, December 21). Telecom Regulatory Policy CRTC 2016-496. Retrieved September 01, 2017, from http://www.crtc.gc.ca/eng/archive/2016/2016-496.htm

Canadian Radio-television and Telecommunications Commission (CRTC). (2016b). Communications Monitoring Report 2016. Retrieved September 01, 2017, from http://www.crtc.gc.ca/eng/publications/reports/policymonitoring/2016/cmr.htm

Canadian Radio-television and Telecommunications Commission. (2016c). CRTC Submission to the Government of Canada's Innovation Agenda. Retrieved September 01, 2017, from http://www.crtc.gc.ca/eng/publications/reports/rp161221/rp161221.htm

Canadian Radio-television and Telecommunications Commission (CRTC). (2017a, March 01). Telecom Decision CRTC 2017-57. Retrieved September 01, 2017, from http://www.crtc.gc.ca/eng/archive/2017/2017-57.htm

Canadian Radio-television and Telecommunications Commission. (2017b). Telecom Notice of Consultation CRTC 2017-112: Call for comments - Development of the Commission's broadband funding regime. Retrieved September 01, 2017 from http://www.crtc.gc.ca/eng/archive/2017/2017-112.htm

Canadian Radio-television and Telecommunications Commission. (2017c). Telecom Regulatory Policy CRTC 2017-200: Review of the Wireless Code. Retrieved September 01, 2017 from http://www.crtc.gc.ca/eng/archive/2017/2017-200.htm 
Conference Board of Canada. (2016). A Looming Skills Gap Threatens Ontario's Future . Retrieved September 01, 2017, from http://www.conferenceboard.ca/infographics/skills-gap-info.aspx

Connect America Fund; Universal Service Reform-Mobility Fund. (2017, March 28). Retrieved September 01, 2017, from https://www.federalregister.gov/documents/2017/03/28/2017-05665/connect-america-funduniversal-service-reform-mobility-fund

Connected Continent for a Future-Proof Europe - EPSC - European Commission. (2016, July 25). Retrieved September 01, 2017, from http://ec.europa.eu/epsc/publications/strategic-notes/connected-continent-future-proof-euro pe en

Consumer Code for Wireless Services. (n.d.). Retrieved September 01, 2017, from https://www.ctia.org/initiatives/voluntary-guidelines/consumer-code-for-wireless-service

Colledge, M. \& Haight, H. (2016). The risk of building infrastructure without building digital literacy. Retrieved September 01, 2017, from https://beta.theglobeandmail.com/report-on-business/rob-commentary/the-risk-of-building-in frastructure-without-building-digital-literacy/article32043633/?ref=http://www.theglobeandm ail.com\&

CRTC Chair Blais Calls Out Telcos For Double-Talk on Internet Fibre Investment. (2017, April 30). Retrieved September 01, 2017, from http://www.michaelgeist.ca/2017/04/crtc-chair-blais-calls-telcos-double-talk-internet-fibre-in vestment/

Deloitte Australia. (2013) Finance, Deloitte Access Economics report. Retrieved September 01, 2017, from

https://www2.deloitte.com/au/en/pages/economics/articles/benefits-high-speed-broadbandaustralian-households.html

Department of Communications. (1986). Canada: World leader in spectrum management [Brochure]. Ottawa, ON: Department of Communications.

Department of Communications. (1992). A spectrum policy framework for Canada. URL: http://wwwJc.gcca/eic/site/smt-gstnsf/vwapj/spfa992-cpcsi992-eng.pdf/\$FTLE/spfa992cpcsi 992-eng.pdf [December 17, 2012].

Digital skills and inclusion - giving everyone access to the digital skills they need. (n.d.).

Retrieved September 01, 2017, from https://www.gov.uk/government/publications/uk-digital-strategy/2-digital-skills-and-inclusiongiving-everyone-access-to-the-digital-skills-they-need

European Union. (2012). EU HIGH LEVEL GROUP OF EXPERTS ON LITERACY Retrieved September 01, 2017, from 
http://ec.europa.eu/dgs/education_culture/repository/education/policy/school/doc/literacy-re port en.pdf

European Union (2016a). Connected Continent for a Future-Proof Europe. Retrieved September 01, 2017, from https://ec.europa.eu/epsc/sites/epsc/files/strategic_note_issue_19.pdf

European Union (2016b). Communications from the Commission to the European Parliament, The Council, The European Economic and Social Committee and The Committee of the Regions. Retrieved September 08, 2017, from, http://ec.europa.eu/newsroom/dae/document.cfm?doc_id\%3D17182\&sa=D\&ust=15048837 30054000\&usg=AFQjCNHYT-giLdEGhKw7rQZuw9E9ZVeQbg

Federal Communication Commission. (2017). Strategies and Recommendations for Promoting Digital Inclusion. Retrieved September 01, 2017, from https://apps.fcc.gov/edocs_public/attachmatch/DOC-342993A1.pdf

Foosaner, N. (2016). The move to spectrum sharing: How reclassification under title II will cause spectrum sharing to dominate telecommunications policy. Federal Communications Law Journal, 68(3), 469.

Geist, M. (2017). Bains Gives Bell-MTS Merger a Pass Despite Competition Bureau Finding Serious Wireless Market Problems. Retrieved Sept 08, 2017, from http://www.michaelgeist.ca/2017/02/bains-gives-bell-mts-merger-a-pass-despite-competitio n-bureau-finding-serious-wireless-market-problems/

Google (2017). Helping prepare for the future of work. Retrieved Sept 01, 2017, from https://www.google.org/helping-prepare-for-the-future-of-work/

Government of Canada. (2017). Budget 2017: Building a Strong Middle Class: Chapter 1 Skills, Innovation and Middle Class Job. Retrieved Sept 01, 2017, from http://www.budget.gc.ca/2017/docs/plan/chap-01-en.html

Governor in Council. (2006). Order Issuing a Direction to the CRTC on Implementing the Canadian Telecommunications Policy Objectives. 2006-12-27 Canada Gazette Part II. Retrieved from http://laws-lois.justice.gc.ca/eng/regulations/SOR-2006-355/page-1.html

Helping prepare for the future of work - Google.org. (n.d.). Retrieved September 01, 2017, from https://www.google.org/helping-prepare-for-the-future-of-work/

ICTC. (2016). Skills in the Digital Economy: Where Canada Stands and The Way Forward. Retrieved from https://www.ictc-ctic.ca/wp-content/uploads/2016/05/Skills-in-the-Digital-Economy-Where-C anada-Stands-and-the-Way-Forward-.pdf 
Industry Canada. (2006). Telecommunications Policy Review Panel.

Industry Canada. (2007b). Policy Framework for the Auction for Spectrum Licences for Advanced Wireless Services and other Spectrum in the $2 \mathrm{GHz}$ Range. Retrieved September 8, 2017, from, https://www.ic.gc.ca/eic/site/smt-gst.nsf/vwapj/awspolicy-e.pdf/\$FILE/awspolicy-e.pdf

Industry Canada. (2012). Policy and Technical Framework Mobile Broadband Services (MBS) $-700 \mathrm{MHz}$ Band. Broadband Radio Service (BRS) - $2500 \mathrm{MHz}$ Band. Retrieved September 08, 2017, from, https://www.ic.gc.ca/eic/site/smt-gst.nsf/vwapj/700MHz-e.pdf/\$file/700MHz-e.pdf

Innovation, Science and Economic Development Canada. (2016). An Inclusive Innovation Agenda: The State of Play

Infrastructure Canada. (2017). Infrastructure Canada's Funding Programs. Retrieved Sept 08, 2017, from http://www.infrastructure.gc.ca/prog/programs-infc-summary-eng.html

Innovation Science and Economic Development Canada. (2017). Consultation on Releasing Millimetre Wave Spectrum to Support 5G. Retrieved from Ottawa: http://www.ic.gc.ca/eic/site/smt-gst.nsf/eng/sf11298.html

Innovation Science and Economic Development Canada. (2017b). Consultation on Releasing Millimetre Wave Spectrum to Support 5G. Retrieved from Ottawa: https://www.canada.ca/en/innovation-science-economic-development/programs/computer-i nternet-access/connect-to-innovate.html

McNally, M. B., Rathi, D., Evaniew, J., \& Gareau-Brennan, C. (2015). Intervention in Response to Canadian Radio-television and Telecommunications Commission Telecom Notice of Consultation CRTC 2015-134. Retrieved from https://services.crtc.gc.ca/pub/ListelnterventionList/Documents. aspx?ID=223980\&en=2015$134 \& d t=i \& l a n g=e \& S=C \& P A=t \& P T=n c \& P S T=a$

MediaSmarts. (2015). Mapping Digital Literacy Policy \& Practice In The Canadian Education Landscape. Retrieved September 01, 2017, from http://digitaliseringsradet.se/en/about-the-digitalisation-council/the-digitalisation-council-s-d uties/

http://mediasmarts.ca/sites/mediasmarts/files/publication-report/full/mapping-digital-literacy. pdf

Mewhort, K., Anderson, S., \& OpenMedia.ca. (2012). Spectrum policy in canada: Leveling the playing field for affordable rates and a breadth of choice OpenMedia.ca.

Middleton, C. A. (2011). Canada's telecommunications policy environment. Telecommunications Journal of Australia, 61(4), 69.61-69.14.

Middleton, C. (2011) Structural and Functional Separation in Broadband Networks: An Insufficient Remedy to Competitive Woes in the Canadians Broadband Market. In Moll, 
Marita and Shade, Leslie Regan. The Internet Tree. pp. 61-72. The Canadian Centre for Policy Alternatives.

Middleton, C. A. (2016). Moral fibre: Should policymakers 'do what is right' and promote all-fibre broadband networks?. Intermedia, 44(1), 31 - 34

McMillan, J. (1994).Selling Spectrum Rights. The Journal of Economic Perspectives, Volume 8, Issue 3, 145 - 162.

Mobile Syrup. (2016). OECD says foreign investment in the telecom sector needed to lower prices in Canada. Retrieved Sept. 01, from,

https://mobilesyrup.com/2016/06/14/oecd-says-foreign-investment-in-the-telecom-sector-ne eded-to-lower-prices-in-canada/

Noam, E. (1998). Spectrum auctions: Yesterday's heresy, today's orthodoxy, tomorrow's anachronism; taking the next step to open spectrum access. Journal of Law and Economics, 41(2), 765.

OECD Broadband Portal: Fixed broadband subscription price ranges. (2015). Retrieved September 1, 2017, from http://dx.doi.org/10.1787/888933224706

OECD Directorate for Science Technology and Industry. (2003). Broadband Driving Growth: Policy Responses. Retrieved September 01, 2017 from http://www.oecd.org/dataoecd/18/3/16234106.pdf

OECD Directorate for Science Technology and Industry. (2008). OECD Policy Guidance on Convergence and Next Generation Networks. Retrieved September 01, 2017 from http://www.oecd.org/dataoecd/14/52/40869934.pdf

Public Works and Government Services Canada, Integrated Services Branch, Government Information Services, Publishing and Depository Services. (2013, April 03). The new national dream: networking the nation for broadband access :: C2-574/2001E - Government of Canada Publications. Retrieved September 01, 2017, from http://publications.gc.ca/site/eng/102167/publication.html

Rajabiun, R., \& Middleton, C. A. (2013). Rural broadband development in Canada's provinces: An overview of policy approaches. Journal of Rural and Community Development, 8(2), 7-22.

Rajabiun, R., \& Middleton, C. (2017). Regulatory federalism and broadband divergence: Implications of invoking Europe in the making of Canadian telecom policy. Intereconomics, 52(4), 217-225. doi:10.1007/s10272-017-0678-3

Sweden, Ministry of Enterprise and innovation. (2017). A Completely Connected Sweden by 2025 - a Broadband Strategy

Taylor, G. (2013). Oil in the ether: A critical history of spectrum auctions in canada. Canadian Journal of Communication, 38(1), 121. 
Telecommunications Industry Ombudsman - Providing independent, just, informal speedy resolution of complaints. (n.d.). Retrieved September 01, 2017, from https://www.tio.com.au/consumers/telecommunications-industry-codes-of-practice

Tucker, R. (2013). The Rise and Fall of Australia's \$44 Billion Broadband Project. Retrieved September 01, 2017, from, https://spectrum.ieee.org/telecom/internet/the-rise-and-fall-of-australias-44-billion-broadban d-project

The Digital Skills and Jobs Coalition. (n.d.). Retrieved September 01, 2017, from https://ec.europa.eu/digital-single-market/digital-skills-jobs-coalition

United States Department of Justice. (2011). Justice Department Files Antitrust Lawsuit to Block AT\&T's Acquisition of T-Mobile. Retrieved September 06, 2017, from https://www.justice.gov/opa/pr/justice-department-files-antitrust-lawsuit-block-att-s-acquisi tion-t-mobile

Ultra-high speed broadband for everyone. (n.d.). Retrieved September 01, 2017, from http://swiftnetwork.ca/

United Kingdom, Department for Culture and Sport. (2017a). Next Generation Mobile Technologies: A 5G Strategy for the UK.

United Kingdom, Department for Culture and Sport. (2017b) UK Digital Strategy. Retrieved Sept 01, from, https://www.gov.uk/government/publications/uk-digital-strategy

Van Gorp, A. F., \& Middleton, C. A. (2010). The impact of facilities and service-based competition on internet services provision in the canadian broadband market. Telematics and Informatics, 27(3), 217-230. doi:10.1016/j.tele.2009.12.001

World Bank (2017). The little data book on information and communication technology 2017 Washington, DC: World Bank.

Industry Canada. (2015). FAQs for ISPs. Retrieved September 01, 2017, from, https://www.ic.gc.ca/eic/site/028.nsf/eng/50009.html

OECD Broadband Statistics to December 2006. (n.d.). Retrieved September 01, 2017, from http://www.oecd.org/sti/broadband/oecdbroadbandstatisticstodecember2006.htm\#TimeSeri $\underline{\text { es }}$

Industry Canada. (2010, October 08). Archived - Broadband Canada-Connecting rural Canadians. Retrieved September 01, 2017, from https://www.ic.gc.ca/eic/site/ich-epi.nsf/eng/02120.html

Tucker, R. S. (2013, November 26). The Rise and Fall of Australia's \$44 Billion Broadband Project. Retrieved September 01, 2017, from https://spectrum.ieee.org/telecom/internet/the-rise-and-fall-of-australias-44-billion-broadban d-project 
Statistics Canada (2015, November 30). Skills in Canada: First Results from the Programme for the International Assessment of Adult Competencies (PIAAC). Retrieved September 01, 2017, from http://www.statcan.gc.ca/pub/89-555-x/89-555-x2013001-eng.htm

Industry Canada (2016, October 12). Archived - Audit of the Broadband Rural and Northern Development Pilot Program-Table of Contents. Retrieved September 01, 2017, from https://www.ic.gc.ca/eic/site/ae-ve.nsf/eng/00352.htm|\#s1_1

Department of Finance. (2017, March 22). Chapter 1 - Skills, Innovation and Middle Class Jobs. Retrieved September 01, 2017, from http://www.budget.gc.ca/2017/docs/plan/chap-01-en.html

Haight, M. (2017, March 24). The risk of building infrastructure without building digital literacy. Retrieved September 01, 2017, from https://www.theglobeandmail.com/report-on-business/rob-commentary/the-risk-of-building-i nfrastructure-without-building-digital-literacy/article32043633/

Blais, J.P. (2017, April 26). CRTC Chair Blais Calls Out Telcos For Double-Talk on Internet Fibre Investment. Retrieved September 01, 2017, from http://www.michaelgeist.ca/2017/04/crtc-chair-blais-calls-telcos-double-talk-internet-fibre-in vestment/

Behar, R. (2017, June 05). Minister Bains instructs CRTC to reconsider decision on mandated wholesale roaming. Retrieved September 01, 2017, from https://mobilesyrup.com/2017/06/05/crtc-sugar-mobile-navdeep-bains/

Jackson, E. (2017, June 13). CRTC's Jean-Pierre Blais blasts feds, creatives, telecoms and $\mathrm{CBC}$ in his last speech as chair. Retrieved September 01, 2017, from http://business.financialpost.com/technology/crtcs-jean-pierre-blais-blasts-feds-creatives-tel ecoms-and-cbc-in-his-last-speech-as-chair

Industry Canada. (2007a, July 30). Audit of the Broadband Rural and Northern Development Pilot Program. Retrieved September 01, 2017, from, https://www.ic.gc.ca/eic/site/ae-ve.nsf/eng/00352.html

Broadband Investment Guide. (n.d.). Retrieved September 01, 2017, from https://ec.europa.eu/digital-single-market/en/news/broadband-investment-guide

Nokia. (2015). Government Broadband Plan. Retrieved September 01, 2017, from https://pages.nokia.com/1523. Diffraction-analysis-market-study.html

OECD Broadband Portal. (2015). Retrieved September 01, 2017, from http://www.oecd.org/sti/broadband/oecdbroadbandportal.ht

Digitaliseringsrådet. (2017). Jkö. Retrieved September 01, 2017, from http://digitaliseringsradet.se/en/about-the-digitalisation-counci//the-digitalisation-council-s-d uties/ 
Hampel, M. (2016). Alberta Supernet. Retrieved September 08, from, https://wiki.cybera.ca/display/DIR/Alberta+SuperNet 